what we are going to do about it? Shall we accept the situation as incurable, the appalling consequences as inevitable, or shall we as a great people, afforded a providential opportunity, extend the invitation and point the way to a sane and reasonable agreement among the nations for the curbing of military ambition and for the limitation of military and naval establishments within bounds calculated to the maintenance of the world's peace?

Will the world accept our invitation?
It unquestionably will, because all nations realize they can not maintain the burdens of competitive armaments. Will the nations keep their pledges? They will-at least, until the conditions which would persuade them to enter into such agreements had entirely passed away; and long before that time we may reasonably hope that all nations shall have learned to settle their differences without the armed conflicts that leaves even the victor exhausted and impoverished.

\title{
Curtailment of Armaments
}

\section{By Hox. Frenerick C. Hicks}

Representative in Congress from the State of New York. Member of Naval Affairs Committee.

$\mathrm{O}$ $\mathrm{NE}$ of the great problems of the age, a problem which has occupied the minds of men since that distant time when man first held a weapon in his hand and fought against his fellow for supremacy, is the question of armaments.

Last winter the Committee on Naval Affairs of Congress, of which I am a member, held hearings on the question of reduction of armaments. The committee was honored by the attendance of many distinguished gentlemen, including General Pershing, Ex-Ambassador and Peace Commissioner Henry White, General Bliss, Peace Commissioner, Secretary Daniels, Sir Philip Gibbs, Acting Secretary of State Davis, and others. The views expressed were strongly in favor of armament reductions.

In a statement made at those hearings by General Bliss, a soldier and a statesman whose views are worthy of deepest consideration, he said with emphasis that if the question of the limitation of military establishments could be submitted to the peoples of the world, to the man at the plow, to the man toiling in the factory and in the office, and to the woman in the home, there would be such an overwhelming verdict in favor of a reduction that the vote against the proposition would be a negligible factor.

If all dangers that lead to wars, or the causes which provoke trouble could be removed, it would follow as a natural corollary that there would be no need of great military establishments at all, but unfortunately for society it does not seem possible to eliminate these causes.

In a statement made by General Wood a number of years ago he said that "nine out of ten wars are based on trade, the other one perhaps on race expansion and in times past upon dynastic influence, but wars arise principally from trade." This statement, I believe, depicts a true conception of the causes of war. Commercial greed and territorial aggrandizement, due to the desire for new fields of exploitation, have been the heart and soul of most of the mighty tragedies that have subverted justice and battered the human race for centuries. Because commer- 
cial jealousies and trade rivalries are ever-increasing elements in our international relationships, there are many who maintain that wars are inevitable and that it is futile to hope for any limitation of armaments, or for any agreement among the nations. Leaving aside the question whether war can be prevented, it seems indisputable that a limitation of armaments is in accord with the opinion of those who contended in the recent war and who hope that peace is something better than a mere truce. After so many sufferings the peoples feel too keenly the imperative necessity of avoiding the disastrous perils of the past, not to make every effort for the reduction in armies and fleets.

\section{Our Military Establishments}

Before discussing the matter in detail I will refer briefly to the cost of our military establishments. For the year ending June 30, 1920, there was appropriated for war purposes, including pensions and care of the disabled, approximately $\$ 5,500,000,000$, while $\$ 400,000,000$ was expended for the civil functions of the government. This is at a ratio of 93 per cent to 7 per cent. For the individuals who have suffered as a result of war there can, of course, be no limit to the expenditures made in grateful appreciation of their services. The reduction in expenditures, if they are to be made, must be made on the material side of the equation and in the account of maintenance of the establishments.

I will take up only the naval side of the question. Consider the unit cost of our fleets. We are now building ten great battleships and six battle cruisers, costing approximately $\$ 38,000,000$ apiece. Our destroyers and submarines are costing $\$ 2,000,000$ and in some cases $\$ 4,000,000$ apiece. The advent of the airplane and its adoption as a military weapon has made necessary a new type of ship, the airplane carrier. These vessels, outside of their equipment, will cost over $\$ 28,000,000$ each, and the cost of the necessary aircraft will run into the millions. But these sums, large as they are, are only the initial costs, for in order to operate these ships, thousands of men must be employed and provided for, enormous drydocks erected and vast shops maintained.

An interesting comparison of cost can be made in the case of the battle cruiser Constitution. The old frigate of that name-Old Ironsides, with whose historic story every school boy is familiar, a ship which in her day was the pride of the Navy-cost $\$ 303,000$. The new Constitution, now being constructed, will cost $\$ 38,000,000$. This represents the naval development of a century and a quarter. The appropriations for the Navy for the year ending June 30,1920 , were $\$ 630,000,000$; for the year ending June $30,1921, \$ 487$,000,000 ; and it is probable that Congress, for the year ending June 30, 1922, will appropriate over $\$ 400,000,000$. I merely mention these figures so that we may have some conception of what it costs to operate the Navy.

I will not enumerate the number of school houses which could be built, nor the number of roads constructed, nor other beneficial improvements made with the money expended in constructing battleships. Neither will I refer to the amount which would be saved in taxes, could the naval program be reduced; it is a mere mathematical calculation, but one which affects the life of every individual. The loss of man power in productive fields caused by the employment of men in the operation of our war vessels, or engaged in the building of ships or the manufacture of munitions of war, is of vital concern. Could these men be utilized in the arts 
of peace, the economic effect on our industrial life would be far-reaching and our problem of production and distribution vastly simplified.

We all look with conscious pride upon the splendid achievements of the American Navy, whose record of service rendered is one of the brightest pages of our history. If America is to stand alone, beset with problems the most portentous in the history of the world, I feel that not only an efficient but a powerful navy is essential if we are to maintain ourselves among the powers, protect our expanding commerce and safeguard the principles upon which the nation is founded. In the absence of any international agreement, the increase of naval strength by other nations compels us to increase our naval force as a measure of protection and precaution. I feel that the sentiment of the country is opposed to the sacrifice of the national interest by curtailing American armament, based on the mere speculation that other nations will do likewise. But the hope is ever present that the time may come when there will be lifted from the hearts of American mothers the fear of deadly conflict, and from the shoulders of our citizens, a part, at least, of the burdens of taxation due to vast armaments. I feel that this happy augury can only be fulfilled by an international agreement to limit armaments.

It is interesting to note that no matter how selfish or covetous a nation may be, the arguments presented for the justification of great military establishments are always for defense of the homeland, never for aggression. Sinister motives are always concealed beneath the cloak of protection. This clouding of the real purpose of nations makes it imperative that America be on guard against the possibility of attack.

\section{Armament or Disarmament}

In viewing this question of curtailment of armaments it would seem that the discussion naturally divides itself among three classes. First, those who do not believe in curtailment of armament under any conditions; second, those who do not believe in maintaining military establishments at all; and third, those who believe in a reduction of these establishments by international agreement. In the first class are those who claim that the lessons of the past prove that no plan of international agreement is practical and that force is the only factor respected in international relations. Personally I feel that these persons, whose sincerity I do not doubt, while loud in their acclaim of the futility of compacts, are neither large in number nor sound in logic. Merely because wars have followed wars down the centuries, with their lessons of anguish unheeded, and because treaties and agreements have been broken;-- these do not seem to be conclusive arguments that no attempt should be made to reach a solution of the problem. It would be as reasonable to contend that because contracts in civil life are violated and criminal law broken, we should abandon all courts and all lawmaking bodies; or because our grandfathers used tallow candles and stage coaches it was foolish for anyone to experiment with the electric light or the automobile.

Advocates of Armaments. These advocates of mighty armaments employ the annals of the past to prove that in the failures of international agreements history but repeats itself, and will continue to repeat itself, and therefore no change is possible. It would seem to me more in accord with the progress of enlightenment to look upon history not merely as a dead record, but rather as a living guide to 
direct our thoughts and our purposes toward greater achievements; to inspire us by the good that was accomplished, and at the same time warn us against the errors that were made. Conceding that wars may occur again, that possibility does not relieve us of the responsibility of seeking to formulate some plan by which the chances of their recurrence may be reduced to a minimum, or excuse us from making every effort to reach an understanding with other nations for the reduction of the burden in anticipation of them.

Advocates of Disarmaments. In the second class are those who are opposed to armaments per se and who, therefore, advocate immediate reduction, or disarmament, irrespective of the action of other nations. They employ as their slogan the catching phrase, "The way to disarm is to disarm," and put forward the proposition that without an agreement an example on our part will lead other nations to disarm. While I realize the potential influence of America in the politics of the world, I doubt if the world itself is willing to follow our lead unquestioned. We are living in a troubled era, with the danger of war ever present, and in my judgment it would be an unwise and an unjustifiable policy for this nation to reduce armaments as an independent action.

Ex-President Taft has said that "Until all nations strongly armed reduce, every wise nation will insist on providing and maintaining an armament enabling it to make effective defense against the possible unlawful aggression of any other armed nation."

These advocates of disarmament also assert that moral suasion will accomplish the desired results. I realize the potency of argument and the value of calm consideration and the earnest presentation of a proposition, but I doubt if any of these factors will be sufficient to cause a reduction of armaments. Let us see if we can learn any lessons from the past. Before the dark clouds of the Revolution gathered in the storm which was eventually to weld the thirteen colonies into one great nation, the statesmen of this country appealed to the motherland for justice and for the equitable settlement of pending difficulties. Speeches, pamphlets, petitions, appeals, set forth the righteous demands of the struggling colonies. From the historic city of Philadelphia was issued the declaration of our principles, that charter of human rights which is the basis of all liberal governments. Was moral suasion sufficient then to compel England to rectify the error of her ways? Let the answer come from Bunker Hill and Saratoga, from Valley Forge and Yorktown and from every hero's grave along our Atlantic seaboard.

When American seamen were being impressed on British ships, were the arguments of statesmen and the appeals of patriots sufficient to protect our rights? When the Mason and Dixon line was the frontier of political doctrines, the dividing line between two schools of thought; when for a quarter of a century debate succeded debate, and argument followed argument; when the convictions of a father were set against the convictions of a son, and brother disputed with brother; when there loomed large on the horizon the danger of civil conflict;-was moral suasion sufficient to avert the coming conflict? Let Antietam and Gettysburg and the tottering veterans of that struggle tell the story. Was moral suasion sufficient to induce Spain to cease her atrocities in Cuba?

When Germany, mad with the lust of blood, seeking world dominion, trampled upon our rights and insulted our flag, were the pleadings and the appeals of our nation effective in 
making her swerve from her course? The answer comes from the valleys and the hilltops of the battle line of France. Moral suasion, regretful though it may be, has not yet become the staff upon which a nation can depend for the protection of its rights.

Advocates of Curtailment. In the third class I put those who favor curtailment of armaments based on an international agreement, and here let me quote from a recent speech of General Pershing.

It is time that enlightened people everywhere should undertake to reach some rational agreement which would not only relieve the world of its heavy financial burden but which in itself would go far toward the prevention of war. We are not a warlike people; we do not wish to expand at the expense of any other nation and we have no design on anybody. Expenditures must be lowered everywhere if financial stability is to be restored and if the nations are ever to pay their debts. Until stability is restored none can have the prosperity that comes from a free and uninterrupted flow of products from one country to another. But this can not be done if huge sums continue to be appropriated for the maintenance of large armies and large navies.

In that statement I believe the overwhelming majority of the American people concur.

To those who say that any agreement is but a mere scrap of paper, $I$ answer by saying that I still have faith in the integrity and the sincerity of international compacts and am not yet ready to admit that deceit and duplicity control the action of men, or of nations. The most striking example in recent history of the efficiency of an international compact can be cited in the agreement which holds inviolate the boundary line between this country and Canada. Without fortifications or dreadnaughts, without guns or bayonets, with nothing more deadly than custom houses, that line while separating two great peoples politically is yet a chain which binds them together in friendship, in respect and in mutual confidence. I desire to congraiulate my colleague, Representative Rogers, on his able and convincing presentation of this important document. ${ }^{1}$ If civilization can not meet the issue and abide by an international agreement whose sole purpose is for the betterment of that civilization, then I fear civilization is not worth the cost it has been to humanity through all the ages.

\section{International Reduction}

To my mind an agreement with the world powers to reduce armaments, or to limit their production, is the only safe, the only logical solution of the problem and I believe that America, free from international complications and entanglements, free from the centuries-old prejudices which have kept Europe in a state of turmoil for a thousand years, free from thoughts of aggrandizement or of territorial aggression, occupies the position in the world today which entitles her to the leadership, yea, which compels her to assume the responsibility of bringing about such an international conference. It must not be overlooked that we are in a position also of being able to establish and maintain the largest navy in the world if we so desire it. We have the wealth, the material and the man power to outstrip in a naval program any and all nations. We make no threat; we desire to enter into no ruinous competition. We seek an amicable adjustment of the problem, and will reduce if the nations will join us in an international compact.

A statement made by Ex-Ambassador Henry White, a noted diplomat, one of our Peace Commissioners in Paris, runs as follows:

${ }^{1}$ See page 62. 
My feeling is that the peoples of the world are hoping for disarmament; that the various nations are crying out for a reduction of their taxation, which, of course, can be brought about only through a reduction of armaments, and $I$ think they are looking to us to take the initiative in bringing it about. As we are the principal power of the world, they are all rather looking to see what we are going to do and, of course, I need not say that, while ardently in favor of disarmament as a general principle, I am not in favor of our being the only nation to disarm.

Which nations are to be invited to attend a disarmament conference is a matter for consideration. It would seem advisable to include only the five great powers, America, Great Britain, France, Italy and Japan, for these are the nations most vitally concerned in curtailment of armament, and are the ones which have the largest organized military forces subject to any appreciable reduction. It is stated that perhaps all of these five might not accept an invitation to attend such a conference. If that should come to pass then those that were sincerely interested in such a compact would know the danger point and could take steps to meet the possibility of a new military despotism. Should any nation violate the agreement or inaugurate a building program in contravention of the compact, then the other nations could either take steps to force compliance with the agreement, or meet the broken pledge by the concentration of such military power as would make futile any aggression by the offending power.

General Bliss says:

Personally, I have no doubt whatever that practical results can still be promptly obtained by a free, fair and unpledged conference of the five great powers. I think it would be most unwise for my country to take any positive step in the direction of disarmament except as the result of an agreement with other powers. In fact, I have constantly maintained that if it were left to me to decide, I would not disarm a single American soldier, nor lay up an American ship, nor cease our military and naval preparation, except as the result of such an international agreement as satisfied us that such a step would be safe and would be good business.

Let me quote again from General Pershing, whose statesmanship vision is illuminating:

As we consider the causes of the World War and comprehend its horrors, every thinking man and woman must feel that measures should be taken to prevent another such calamity. One step in that direction would be to reduce expenditures for armament, but one nation can not reduce armaments unless all do. The safety of humanity of the future, indeed the peace, the happiness and prosperity of the race, all appeal alike for an early consideration of the question of limitation of armaments.

As to the method of limiting or reducing armaments, I have no suggestion to offer. That the problem can be worked out satisfactorily I have no doubt; but until such a conference is held, the discussion of various schemes of disarming seems to me aimless and futile, and until such an agreement is made I feel we should push forward to completion our naval program. Our strength will then give us a relative position, so that when reductions are made we will stand on terms of equality with any nation in the world, an equality justified by our resources, our interests and our vast area.

If America were now to suspend construction, it would give an impetus to building by other powers to the extent that when the time came for making proportionate reductions this country would find its fleet in third or fourth place. In my opinion this is a status which thegreat majority of the American people would not be satisfied to occupy.

If we reduced as an independent ac- 
tion and other nations continued their building programs we would shortly be in a position where our influence would be insignificant, for it must be conceded that a nation with little to reduce can not be a potent factor in any conference on reduction. A large fleet not only affords protection pending the formulation of an agreement, but it gives us influence in world affairs and guarantees our good faith in entering into a compact, for the reduction of a powerful navy with the losses which will be sustained will be proof of our earnest and sincere purpose.

\section{Presidential Action}

The time when this conference should be called and the course to be pursued is a question not for Congress but for the Chief Executive. The Constitution contemplates that his judgment shall mark the nation's policy in developing international relations. In his hands rest the responsibilities of our foreign intercourse, and while I am a sincere believer in an international compact to reduce armament and to limit this mad race of competitive building of military establishments, I would not jeopardize the safety of America or the adjustment of world difficulties, now so threatening, by forcing the hand of our President. I am willing to abide by his decision as to when this conference shall be called. By his public utter- ances, and by his addresses, President Harding is in sympathy with the movement for a limitation of armaments. Actuated by the highest motives, farseeing, sincere and patriotic, this great question which affects the destiny of America and the destiny of civilization can safely be entrusted to his decision.

Until he feels that the world relationships have been sufficiently stabilized to warrant his calling such a conference, let us be patient, let us remember the responsibilities that confront this great Republic, and be mindful of conditions across the seas. Dynasties have crumbled, new nations have risen upon the ruins of ancient empires, and against the outposts of stable governments surge the onslaughts of anarchy and the red forces of disorder and discord. Hate, prejudice and bitterness are united in a mad orgy to subvert the principles for which humanity has contended for centuries.

Discontent and rebellion against established law permeate every phase of our economic, social and political life. A false step now might engulf the world in darkness; precipitate action might destroy the last bulwark of liberty and sweep away the hope that we are at the dawn of a new era, when the ideals of justice, of mutual confidence and lasting peace, will shed their beneficent mantle over the world.

\title{
Reduction of Armaments
}

\author{
By Hon. John Jacob Rogers \\ House of Representatives, Washington, D. C.
}

\begin{abstract}
$\mathrm{N}$ any discussion of reduction of armaments the following propositions seem to me fundamental:
\end{abstract}

First, Until a program for the reduction of armaments is agreed to by the principal nations of the world, including the United States, it should be the policy of this country that our Navy should be second to none.

Second, That an international conference to consider the reduction of armaments should at the earliest practicable moment be called by the President of the United States to meet in this country.

Third, That the countries invited by 